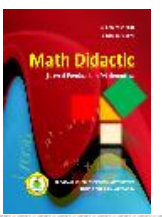

MATH DIDACTIC: JURNAL PENDIDIKAN MATEMATIKA

Volume 4 Nomor 1, Januari - April 2018, halaman 34- 46

Tersedia Daring pada http://jurnal.stkipbjm.ac.id/index.php/math

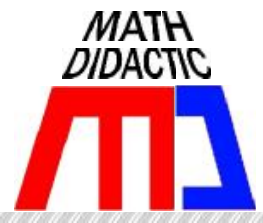

\title{
PROFIL BERPIKIR REFLEKTIF SISWA DALAM MENYELESAIKAN SOAL TIPE-TIPE PERKALIAN DITINJAU DARI PERBEDAAN KEMAMPUAN MATEMATIKA DAN GENDER
}

\section{PROFILE OF REFLECTIVE THINKING STUDENTS IN RESOLVING PROBLEMS TYPES MULTIPLICATION BASED ON DIFFERENCE MATH ABILITIES AND GENDER}

\author{
Agustina Sukarno Putri, Helti Lygia Mampouw \\ Pendidikan Matematika Fakultas Keguruan dan Ilmu Pendidikan Universitas Kristen Satya Wacana Salatiga \\ 202014009@student.uksw.edu , helti.mampouw@staff.uksw.edu
}

\begin{abstract}
Abstrak: Berpikir reflektif berhubungan dengan kemampuan untuk mereview, memantau dan memonitor proses solusi pada saat melakukan pemecahan masalah. Penelitian kualitatif ini bertujuan untuk mendeskripsikan kemampuan berpikir reflektif siswa SMP dalam menyelesaikan soal cerita tipe scalar multiplication, array multiplication dan combinatorial multiplication berdasarkan perbedaan kemampuan matematika dan gender. Subjek terdiri atas 3 siswa laki-laki dan 3 siswa perempuan kelas VII SMP yang masing-masing memiliki kemampuan matematika tinggi, sedang dan rendah. Hasil penelitian menunjukkan bahwa siswa laki-laki dan perempuan berkemampuan matematika tinggi memiliki kemampuan berpikir reflektif untuk semua tipe soal. Siswa berkemampuan matematika sedang memiliki kemampuan berpikir reflektif untuk tipe scalar multiplication dan cukup reflektif pada tipe combinatorial multiplication. Siswa laki-laki berkemampuan matematika rendah cenderung kurang reflektif pada semua tipe soal dan siswa perempuan memiliki kemampuan berpikir reflektif pada semua tipe soal. Ditemukan juga bahwa siswa laki-laki cenderung mampu menggunakan ilustrasi, misalnya dengan gambar sedangkan siswa perempuan cenderung menyelesaikan soal secara teratur, misalnya dengan menuliskan diketahui, ditanya, dan dijawab. Dari hasil penelitian ini diharapkan dapat membantu guru dan peneliti lain untuk memahami tingkat berpikir reflektif siswa pada tipe perkalian ditinjau dari perbedaan kemampuan matematika dan gender.
\end{abstract}

Kata Kunci: berpikir reflektif, tipe-tipe perkalian, kemampuan matematika, gender

Abstract: Reflective thinking is concerned with the ability to review, monitor, and monitor the solution process when troubleshooting. This qualitative research aims to describe the reflective thinking ability of junior high school student in solving the problem of scalar multiplication type, array multiplication and combinatorial multiplication based on different ability of math and gender. The subjects consisted of 3 male students and 3 female students of grade VII SMP who each had high, medium and low math skills. The result show taht male and female students with high math skills have reflective thinking skills for all type of questions. Student with math skills are capable of reflective thinking for scalar multiplication types and reflective enough in combinatorial multiplication types. Male students with low math skills tend to be less reflective on all types of questions and female students have reflective thinking skills on all types have reflective. It was also ound that male students tend to be able to use ilustrations, for example with pictures whereas female students tend to solve problems on a regular basis for example by writing known, questioned, and answered. These results are expected to help teachers and researchers to understand the level of reflective thinking of students on the type of multiplication in terms of differences in mathematical ability and gender.

Keywords: reflective thinking, types of multiplication, mathematical ability, gender

Cara sitasi: Putri, A.S., \& Mampouw, H.L. (2018). Profil berpikir reflektif siswa dalam menyelesaikan soal tipe-tipe perkalian ditinjau dari perbedaan kemampuan matematika dan gender. Math Didactic: Jurnal Pendidikan Matematika, 4(1), 34-46. 
Matematika adalah salah satu mata pelajaran wajib yang ada pada jenjang pendidikan dasar hingga perguruan tinggi. Matematika dapat membentuk pemikiran yang logis, kritis, kreatif dan sistematis. Kemampuan memahami masalah, merancang model matematika, ketika mereka bertanya, dan ketika mereka menjelaskan atau menyelidiki kebenaran ide mereka sendiri. Berpikir reflektif merupakan salah satu keterampilan yang dapat mendukung kemampuan berpikir reflektif siswa dalam memecahkan masalah. Dewey mengungkapkan bahwa pendidikan merupakan proses sosial dimana anggota masyarakat yang belum matang (terutama anak-anak) terlibat didalam masyarakat, dengan tujuan dapat memberikan kontribusi dalam perkembangan pribadi dan sosial seseorang melalui pengalaman dan pemecahan masalah yang berlangsung secara reflektif. Sejalan dengan hal itu Bruning (Jiuan, 2007, hal.15) menyatakan bahwa proses berpikir reflektif melibatkan kemahiran berpikir seperti menafsirkan masalah, membuat kesimpulan, menilai, menganalisis, kreatif, dan metakognitif. Surbeck, Han, dan Moyer mengidentifikasi tiga tingkat reflektif yaitu: 1) Reacting: bereaksi dengan perhatian pribadi terhadap peristiwa/situasi/masalah, Elaborating/Comparing: membandingkan reaksi dengan pengalaman yang lain, seperti mengacu pada prinsip umum, suatu teori, 3) Contemplating: mengutamakan pengertian pribadi yang mendalam yang bersifat membangun terhadap permasalahan atau berbagai kesulitan. Berpikir reflektif tidak hanya berpusat kepada pengetahuan yang dimiliki oleh peserta didik saja, namun proses bagaimana memanfaatkan pengetahuan yang sudah dimilikinya untuk memecahkan suatu permasalahan. Jika peserta didik dapat menemukan cara untuk dapat memecahkan suatu permasalahan tersebut sehingga tujuannya tercapai maka peserta didik tersebut telah melakukan proses berpikir reflektif.

Masalah matematika digambarkan sebagai persoalan atau tantangan dimana seorang siswa tidak langsung mengetahui bagaimana cara atau prosedur khusus yang bisa digunakan untuk menyelesaikan masalah tersebut (Wahyuni, 2015, hal.10). Pemecahan masalah adalah proses yang melibatkan penggunaan langkah-langkah tertentu (heuristik), yang sering disebut dengan metode atau langkah-langkah pemecahan masalah untuk menemukan solusi masalah itu (Nakin dalam Ali, 2008, hal.3). Pemecahan masalah mempunyai peran penting dalam pembelajaran matematika. Pemecahan masalah mempunyai berbagai peran, yaitu 1) pemecahan masalah sebagai konteks matematika (problem solving as a context for doing mathematics), yakni memfungsikan masalah sebagai pemicu bagi siswa dan memotivasinya untuk belajar matematika; 2) pemecahan masalah sebagai keterampilan (problem solving as a skill) yang merujuk pada kemampuan kognitif siswa dalam menyelesaikan masalah; dan 3) pemecahan masalah sebagai seni (problem solving as a art) yang merujuk pada pandangan bahwa pemecahan masalah sebagai seni menemukan (art of discovery) (Ali, 2008, hal.6).

\section{Langkah-Langkah Pemecahan Masalah}

Langkah-langkah pemecahan masalah menurut John Dewey (Sanjaya, 2006, hal.217) meliputi:

a) Merumuskan masalah, yaitu langkah menentukan masalah yang dipecahkan. 
b) Menganalisis masalah, yaitu langkah siswa meninjau masalah secara kritis dari berbagai sudut pandang.

c) Merumuskan hipotesis, yaitu langkah siswa merumuskan berbagai kemungkinan pemecahan sesuai dengan pengetahuan yang dimilikinya.

d) Mengumpulkan data, yaitu langkah siswa mencari dan menggambarkan informasi yang diperlukan untuk pemecahan masalah.

e) Pengujian hipotesis, yaitu langkah siswa mengambil atau merumuskan kesimpulan sesuai dengan penerimaan dan penolakan hipotesis yang diajukan.

Berkaitan dengan pembelajaran matematika, gender juga memiliki peran. Siswa laki-laki memiliki kemampuan menerima pembelajaran matematika yang berbeda dengan siswa perempuan. Istilah gender dan seks memiliki perbedaan dari segi dimensi (Santrock, 2011, hal.227-230). Istilah seks (jenis kelamin) mengacu pada dimensi biologis seorang laki-laki dan perempuan, sedangkan gender mengacu pada dimensi sosial-budaya seorang laki-laki dan perempuan. Gender adalah perbedaan peran, fungsi, dan tanggungjawab antara laki-laki dan perempuan yang merupakan hasil konstruksi sosial dan dapat berubah sesuai dengan perkembangan jaman. Setelah mengkaji beberapa definisi gender yang dikemukakan para ahli, dapat dipahami bahwa yang dimaksud gender adalah karakteristik laki-laki dan perempuan berdasarkan dimensi sosial-kultural yang tampak dari nilai dan tingkah laku.

Selain itu, istilah gender merujuk pada karakteristik dan ciri-ciri sosial yang diasosiasikan pada laki-laki dan perempuan. Perbedaan cara mengerjakan soal matematika pada siswa laki-laki yang lebih cenderung menggunakan strategi spatial dan siswa perempuan cenderung menggunakan strategi verbal (Asmaningtias, 2012, hal.13). Berdasarkan penjelasan tersebut, gender memiliki pengaruh dalam pembelajaran matematika di sekolah menengah.

Perkalian adalah salah satu operasi hitung dasar matematika yang telah dipelajari di bangku Sekolah Dasar selain penjumlahan, pengurangan, dan pembagian. "jika a dan $b$ bilangan-bilangan cacah maka $\mathrm{a} \times \mathrm{b}$ adalah penjumlahan berulang yang mempunyai arti a sebagai suku, dan setiap suku sama dengan b" adalah definisi perkalian menurut salah satu ensiklopedia matematika. Operasi perkalian banyak digunakan dalam berbagai macam bentuk soal termasuk soal cerita. Pada soal cerita operasi perkalian di bagi menjadi beberapa tipe, Pascual-Leone (Ferrari, 2010, hal.62) membaginya menjadi tiga tipe, yaitu:

\section{a. Scalar Multiplication}

Scalar multiplication berlaku pada situasi dimana ada beberapa kelompok objek-objek yang memiliki jumlah yang sama di setiap kelompoknya. Sebagai contoh Pascal-Leone menuliskan : "three children have four cookies each. How many cookies do they have altogheter?". Contoh lain yang ia berikan ialah "today at store 1 candy cost 5 cent. How much will 3 candies cost?".

\section{b. Array Multiplication ( a type of Cartesian Problem)}

Untuk dapat memahami tipe perkalian ini, seseorang harus dapat memvisualisasikan atau membayangkan 2 nilai yang berbeda dalam permasalahan ini ke dalam bentuk kolom dan baris serta tampilan yang diciptakan dari 2 dimensi tersebut. Pascual-Leone memberikan contoh gambaran soal sebagai berikut : "we are baking cookies. If we can fit 5 cookies along the long side of the ray and 3 cookies along the short side of the tray, how many 
cookies can we bake on the tray?'. Untuk menyelesaikan masalah ini sebagai Array Problem, seseorang harus mengenali bahwa jumlah pada satu sisi terpanjang (misalkan 5 roti) untuk pengulangan yang lain sisi terpendek (3 roti). Tipe perkalian ini berhubungan dengan 2 kesatuan dimensi yang tidak berubah dan tetap.

c. Combinatorial Multiplication ( a type of Cartesian Problem)

Combinatorial multiplication adalah tipe perkalian yang melibatkan pembentukan sebuah satuan komposit (gabungan) baru (atau unit) dari dua satuan yang berbeda dan lebih sederhana. Unit baru yang dibentuk dari dua unit yang berbeda itu secara semantik berbeda jika dibandingkan dengan unit asalnya. Contoh dalam tipe perkalian ini adalah : "Brian has 6 shirts and 3 pairs of pants. How many different outfits can he make with all his shirts and pants?".

Menyelelesaikan variasi-variasi masalah perkalian dapat membantu siswa untuk memahami bagaimana operasi perkalian dapat diaplikasikan dalam situasi yang berbeda. Selain itu Ontario education dalam buku Number sense and Numeration, grades 4 to 6 volume 3 Multiplication (Ferrari, 2006, hal.13) juga menjelaskan mengenai tipe-tipe perkalian yang teridi dari Equal-Group Problems, Multiplicative Comparison Problem, dan Array Multiplication

Meskipun siswa-siswi telah mempelajari perkalian beserta aplikasi dalam bentuk soal cerita sejak di sekolah dasar, namun mereka tidak diajarkan tipe-tipe perkalian ini. Makalah ini ditulis dengan tujuan mendeskripsikan kemampuan berpikir reflektif siswa dalam menyelesaikan soal pada tipe-tipe perkalian yang ditinjau dari perbedaan kemampuan matematika dan gender. Dalam penelitian ini penulis mengacu pada pendapat Pascal-Leone, yang menyebutkan 3 tipe perkalian yaitu Scalar Multiplication, Array Multiplication, dan Combinatorial Multiplication.

\section{Metode Penelitian}

Penelitian kualitatif ini mendeskripsikan kemampuan berpikir reflektif yang dimiliki siswa dalam menyelesaikan soal cerita berdasarkan tipe scalar multiplication, array multiplication dan combinatorial multiplication yang didasarkan pada langkah pemecahan masalah John Dewey dan berpikir reflektif Surbeck Hand Moyer.

Subjek dari penelitian ini adalah 6 siswa kelas VII A SMP Kristen Satya Wacana Salatiga. Subjek terdiri dari 3 siswa laki-laki dan 3 siswa perempuan. Kategori kemampuan matematika didasarkan pada hasil penilaian akhir semester ganjil tahun ajaran 2017/2018. Berikut profil keenam subjek penelitian dapat dilihat pada tabel 1.

Tabel 1. Profil Enam Subjek Penelitian

\begin{tabular}{ccc}
\hline Subjek & Gender & $\begin{array}{c}\text { Kemampuan } \\
\text { Matematika }\end{array}$ \\
\hline N & Perempuan & Tinggi \\
X & Laki-laki & Tinggi \\
A & Perempuan & Sedang \\
S & Laki-laki & Sedang \\
T & Perempuan & Rendah \\
G & Laki-laki & Rendah \\
\hline \multicolumn{2}{c}{ Keenam subjek diberikan soal tes }
\end{tabular}
yang sama terdiri dari tiga tipe soal cerita yaitu scalar multiplication, array multiplication dan combinatorial multiplication. Penelitian ini adalah penelitian kualitatif maka peneliti berperan sebagai instrumen utama dalam mengumpulkan data, yang dibantu dengan instrumen pendukung yaitu tes tertulis yang berisi soal cerita tipetipe perkalian dan akan digunakan untuk 
menguji kemampuan berpikir reflektif siswa. Soal berbentuk uraian, yang bertujuan untuk melihat proses berpikir reflektif siswa dalam menyelesaikan soal cerita matematika pada tipe-tipe perkalian.

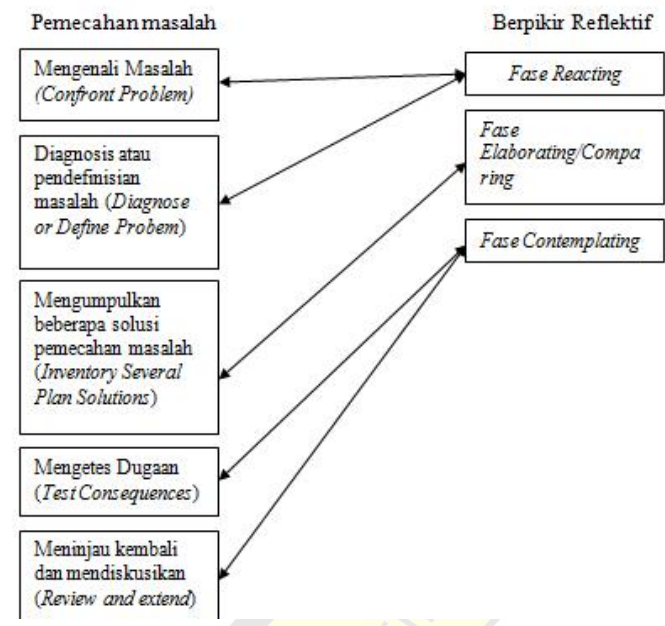

\section{Gambar 1. Keterkaitan Berpikir Reflektif dan Pemecahan Masalah}

Tabel 2. Indikator Berpikir Reflektif dalam Memecahkan Masalah pada Tipe Perkalian

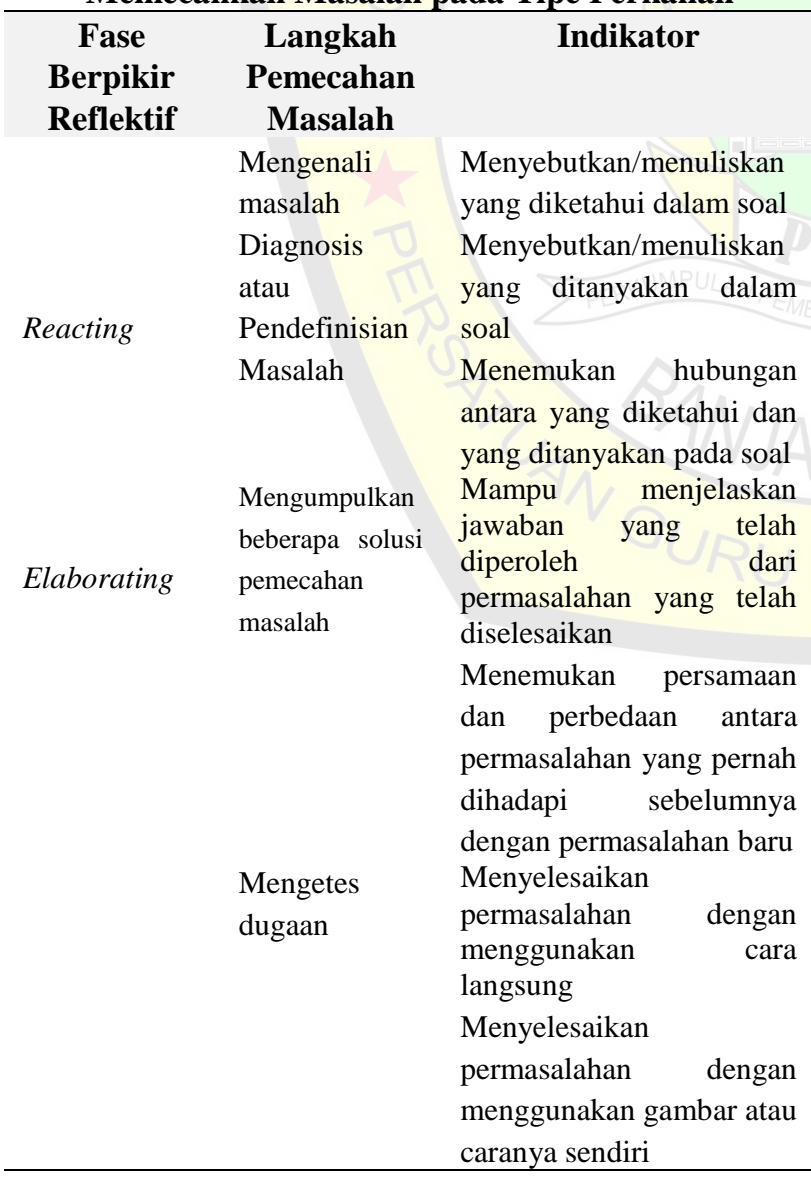

\begin{tabular}{lllr}
\hline Contemplating & Meninjau & Memeriksa & kembali \\
& kembali dan & jawaban yang & telah \\
mendiskusikan & diperoleh & \\
& & Memperbaiki & dan \\
& menjelaskan & jika \\
& menemukan & kesalahan \\
& pada saat menyelesaikan \\
& soal & \\
& Membuat kesimpulan dari \\
& permasalahan yang telah \\
& diselesaikan \\
\hline
\end{tabular}

Fase atau tingkatan berpikir reflektif dapat diketahui sebagai berikut :

1) Reflektif

Pada fase ini dikatakan reflektif karena dapat melalui tiga fase berpikir reflektif yaitu reacing, elaborating dan contemplating.

2) Cukup reflektif

Pada fase ini siswa dikatakan cukup reflektif karena dapat melalui fase reacting dan elaborating yaitu dapat memahami masalah serta mengaitkan masalah yang ada dengan permasalahan lain yang hampir sama dan pernah dihadapi.

3) Kurang Reflektif

Pada fase ini siswa dikatakan kurang reflektif karena hanya melalui fase reacting yaitu bisa melakukan pemahaman terhadap masalah yang dihadapi melalui beberapa indikator di atas.

\section{Hasil Penelitian Dan Pembahasan}

Hasil

Profil berpikir reflektif siswa dalam menyelesaikan soal cerita tipe scalar multiplication

Subjek Berkemampuan Matematika Tinggi

Berdasarkan hasil analisis dari tes tertulis yang diperkuat dengan wawancara yang dilakukan pada subjek $\mathrm{X}$ didapatkan 
pada fase reacting dapat memahami masalah yang dihadapi dengan menyebutkan apa saja yang diketahui dan ditanyakan pada soal serta dapat menemukan hubungan antara yang diketahui dan yang ditanyakan pada soal. Selanjutnya pada fase elaborating mampu menjelaskan jawaban yang telah didapat dari permasalahan yang telah diselesaikan serta mampu menemukan persamaan dan perbedaan dari permasalahan yang pernah dihadapi sebelumnya dengan permasalahan yang sedang dihadapi. Persamaan dalam soal ini adalah menyelesaikan soal yang berkaitan dengan harga, perbedaannya masalah sebelumnya mencari sisa uang. Selanjutnya pada fase contemplating subjek dapat menyelesaika dengan dua cara yaitu dengan cara langsung dan menggunakan gambar. Maka dapat disimpulkan subjek berkemampuan matematika tinggi laki-laki memiliki kemampuan berpikir reflektif pada soal cerita tipe scalar multiplication.

Sedangkan subjek berkemampuan matematika tinggi perempuan ditemukan hasil pada fase reacting dapat memahami masalah yang dihadapi dengan menyebutkan apa saja yang diketahui dan ditanyakan pada soal serta dapat menemukan hubungan antara yang diketahui dan yang ditanyakan pada/soal. Selanjutnya pada fase elaborating mampu menjelaskan jawaban yang telah didapat dari permasalahan yang telah diselesaikan serta mampu menemukan persamaan dan perbedaan dari permasalahan yang pernah dihadapi sebelumnya dengan permasalahan yang sedang dihadapi. Selanjutnya pada fase contemplating subjek dapat menyelesaikan secara teratur, dan membuat kesimpulan dari soal yang telah diselesaikan. Maka dapat disimpulkan subjek berkemampuan matematika tinggi perempuan memiliki kemampuan berpikir reflektif pada soal cerita tipe scalar multiplication.

\section{Subjek Berkemampuan Matematika Sedang}

Subjek laki-laki S ditemukan hasil pada fase reacting subjek dapat memahami masalah yang dihadapi, mengucapkan apa yang diketahui dan ditanyakan pada soal serta dapat menemukan hubungan antara yang diketahui dan yang ditanyakan pada soal. Selanjutnya pada fase elaborating subjek mampu menjelaskan jawaban yang telah ia peroleh dari permasalahan yang telah ia selesaikan. Subjek S mengungkapkan persamaan dalam soal ini adalah menghitung mengenai biaya dan tidak memiliki perbedaan dengan soal yang pernah ia jumpai sebelumnya. Pada fase contemplating subjek dapat menyelesaikan soal. Pada saat mengecek kemabali jawaban yang telah ia peroleh, ia menemukan kesalahan yaitu pada bagian mengalikan jumlah buku dengan harga. Pada fase ini juga subjek dapat membuat kesimpulan. Maka dapat disimpulkan bahwa subjek laki-laki berkemampuan matematika sedang memiliki kemampuan berpikir reflektif pada soal cerita tipe scalar multiplication.

2. Sandy membeli lima buah buku tulis dan tiga buah bolpoin. Jika harga satu buah buku adalah Rp3.500,00 dan harga satu buah bolpoin adalah Rp1.500,00 berapa yang harus dibayarkan Sandy? Jawab :

$3.500,00-\times 5=10.500,000$

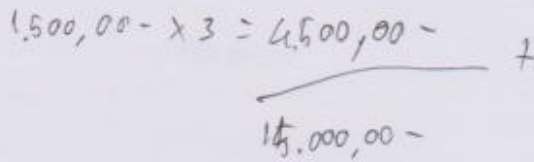

gadi yang harus dibayar so ndo adalah it.ooxpo Gambar 2. Hasil Pekerjaan Subjek S 
Sedangkan subjek perempuan A ditemukan hasil pada fase reacting ia dapat memahami masalah yang dihadapi dengan mengucapkan apa yang diketahui dan yang ditanyakan, serta dapat menemukan hubungan angtara yang diketahui dan yang ditanyakan pada soal. Selanjutnya pada fase elaborating subjek mampu menjelaskan jawaban yang telah didapatkan dari permasalahan yang telah diselesaikan. Maka dapat disimpulkan bahwa subjek perempuan A memiliki kemampuan cukup reflektif pada soal cerita tipe scalar multiplication.

Subjek Berkemampuan Matematika Rendah

Subjek laki-laki $\mathrm{G}$ ditemukan hasil pada fase reacting dapat memahami soal yang dimaksud dan pada fase elaborating dapat menyelesaikan soal tersebut dengan cara langsung dan cara menggambar serta dapat menjelaskan jawaban yang telah diperoleh. Maka dapat disimpulkan subjek $G$ memiliki kemampuan cukup reflektif pada soal cerita tipe scalar multiplication.

Sedangkan subjek perempuan $\mathrm{T}$ ditemukan hasil pada fase reacting dapat memahami soal yang dimaksud dengan menuliskan yang diketahui pada soal dan menyebutkan yang ditanyakan pada saat wawancara. Pada fase elaborating ia dapat menyelesaikan soal tersebut serta menjelaskan jawaban yang telah ia peroleh. Selanjutnya pada fase contemplating ia dapat membuat kesimpulan, maka berdasarkan uraian singkat diatas dapat disimpulkan bahwa subjek perempuan berkemampuan matematika rendah memiliki kemampuan berpikir reflektif pada soal cerita tipe scalar multiplication.

\section{Profil berpikir reflektif siswa dalam menyelesaikan soal cerita tipe array multiplication}

\section{Subjek Berkemampuan Matematika Tinggi}

Berdasarkan hasil analisis dari tes tertulis yang diperkuat dengan wawancara yang dilakukan pada subjek laki-laki $\mathrm{X}$ didapatkan bahwa subjek pada fase reacting dapat memahami masalah yang dihadapi, menyebutkan apa saja yang diketahui dan ditanyakan pada soal serta dapat menemukan hubungan antara yang diketahui dan yang ditanyakan pada soal. Selanjutnya pada fase elaborating mampu menjelaskan jawaban yang telah didapat dari permasalahan yang telah diselesaikan serta mampu menemukan persamaan dan perbedaan dari permasalahan yang pernah dihadapi sebelumnya dengan permasalahan yang sedang dihadapi. Selanjutnya pada fase contemplating subjek dapat menyelesaika dengan dua cara yaitu dengan cara langsung dan menggunakan gambar. Maka dapat disimpulkan subjek $\mathrm{X}$ memiliki kemampuan berpikir reflektif pada soal cerita tipe array multiplication .

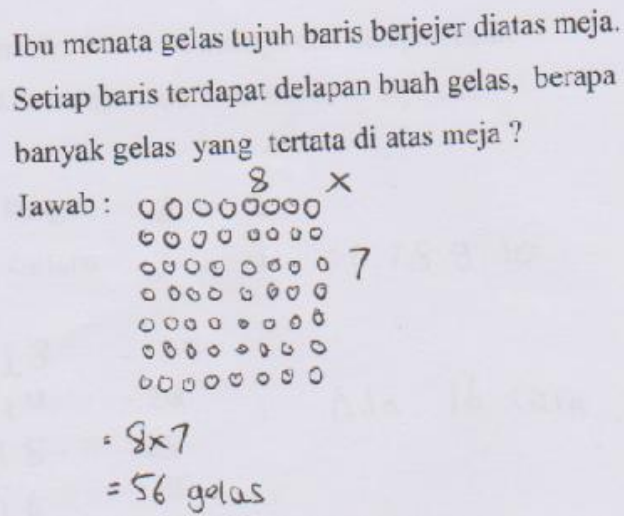

\section{Gambar 3. Hasil Pekerjaan Subjek X}

Sedangkan subjek perempuan N ditemukan hasil pada fase reacting dapat memahami masalah yang dihadapi dengan menuliskan apa saja yang diketahui dan ditanyakan pada soal serta dapat menemukan hubungan antara yang diketahui dan yang ditanyakan pada soal. Selanjutnya pada fase 
elaborating mampu menjelaskan jawaban yang telah didapat dari permasalahan yang telah diselesaikan serta mampu menemukan persamaan dan perbedaan dari permasalahan yang pernah dihadapi sebelumnya dengan permasalahan yang sedang dihadapi. Selanjutnya pada fase contemplating subjek dapat menyelesaikan dan membuat kesimpulan dari soal yang telah diselesaikan. Maka dapat disimpulkan subjek perempuan $\mathrm{N}$ memiliki kemampuan berpikir reflektif pada soal cerita tipe array multiplication .

4. Ibu menata gelas tujuh baris berjejer diatas meja. Setiap baris terdapat delapan buah gelas, berapa banyak gelas yang tertata di atas meja ? Jawab :

Diket =lbu menata 7 baris gelas

I baris terdapat Ogelas

Ditanya $=$ Berapa gelas soluruhnya

Jawab: $7 \times 8: 56$

Pernyataan. Jadi ada 56 gelas yang tertata di atas meja

Gambar 4. Hasil Pekerjaan Subjek N

\section{Subjek Berkemampuan Matematika Sedang}

Subjek laki-laki S ditemukan hasil pada fase reacting subjek dapat memahami masalah yang dihadapi, mengucapkan apa yang diketahui dan ditanyakan pada soal serta dapat menemukan hubungan antara yang diketahui dan yang ditanyakan pada soal. Selanjutnya pada fase elaborating subjek mampu menjelaskan jawaban yang telah ia peroleh dari permasalahan yang telah ia selesaikan. Pada fase contemplating subjek dapat menyelesaikan soal tersebut dan dapat membuat kesimpulan. Maka dapat disimpulkan bahwa subjek $\mathrm{S}$ memiliki kemampuan berpikir reflektif pada soal cerita tipe array multiplication.

Sedangkan subjek perempuan A hasil pada fase reacting ia dapat memahami masalah yang dihadapi, mengucapkan apa yang diketahui dan yang ditanyakan, serta dapat menemukan hubungan angtara yang diketahui dan yang ditanyakan pada soal. Namun tidak dapat menyelesaikan permasalahan karena subjek merasa belum pernah menjumpai soal yang serupa. Maka dapat disimpulkan bahwa subjek perempuan A memiliki kemampuan kurang reflektif pada soal cerita tipe array multiplication.

6.

Sebelum masuk ruang kelas siswa siswi kelas $7 \mathrm{~A}$. berbanjar lima bersaf dan siswa laki-laki berbaris tiga berbanjar enam bersaf. Berapa banyak siswa kelas 7 A yang sedang berbaris? Jawab: 5 bersaf

\section{Gambar 5. Hasil Pekerjaan Subjek A}

Subjek Berkemampuan Matematika Rendah

Subjek laki-laki $\mathrm{G}$ ditemukan hasil pada fase reacting dapat memahami soal yang dimaksud dan pada fase elaborating dapat menyelesaikan soal tersebut dengan cara langsung serta dapat menjelaskan jawaban yang telah diperoleh. Maka dapat disimpulkan subjek G memiliki kemampuan cukup reflektif pada soal cerita tipe array multiplication.

Subjek perempuan $\mathrm{T}$ ditemukan hasil pada fase reacting dapat memahami soal yang dimaksud dengan menuliskan yang diketahui pada soal serta dapat mengucapkannya pada saat wawancara. Pada fase elaborating ia dapat menyelesaikan soal tersebut serta menjelaskan jawaban yang telah ia peroleh. Selanjutnya pada fase contemplating ia dapat membuat kesimpulan, maka berdasarkan uraian singkat diatas dapat disimpulkan bahwa subjek perempuan $\mathrm{T}$ memiliki kemampuan berpikir reflektif pada soal cerita tipe array multiplication. 


$\begin{array}{lccr}\text { Profil berpikir } & \text { reflektif } & \text { siswa } & \text { dalam } \\ \text { menyelesaikan } & \text { soal } & \text { cerita } & \text { tipe } \\ \text { combinatorial multiplication } & & \end{array}$

\section{Subjek Berkemampuan Matematika Tinggi}

Berdasarkan hasil analisis dari tes tertulis yang diperkuat dengan wawancara yang dilakukan pada subjek berkemampuan matematika tinggi laki-laki $\mathrm{X}$ didapatkan bahwa subjek pada fase reacting dapat memahami masalah yang dihadapi, menyebutkan apa saja yang diketahui dan ditanyakan pada soal serta dapat menemukan hubungan antara yang diketahui dan yang ditanyakan pada soal. Selanjutnya pada fase elaborating mampu menjelaskan jawaban yang telah didapat dari permasalahan yang telah diselesaikan serta mampu menemukan persamaan dan perbedaan dari permasalahan yang pernah dihadapi sebelumnya dengan permasalahan yang sedang dihadapi. Selanjutnya pada fase contemplating subjek dapat menyelesaika dengan dua cara yaitu dengan cara langsung dan menggunakan pengelompokkan. Maka dapat disimpulkan subjek $\mathrm{X}$ memiliki kemampuan berpikir reflektif pada soal cerita tipe combinatorial multiplication.

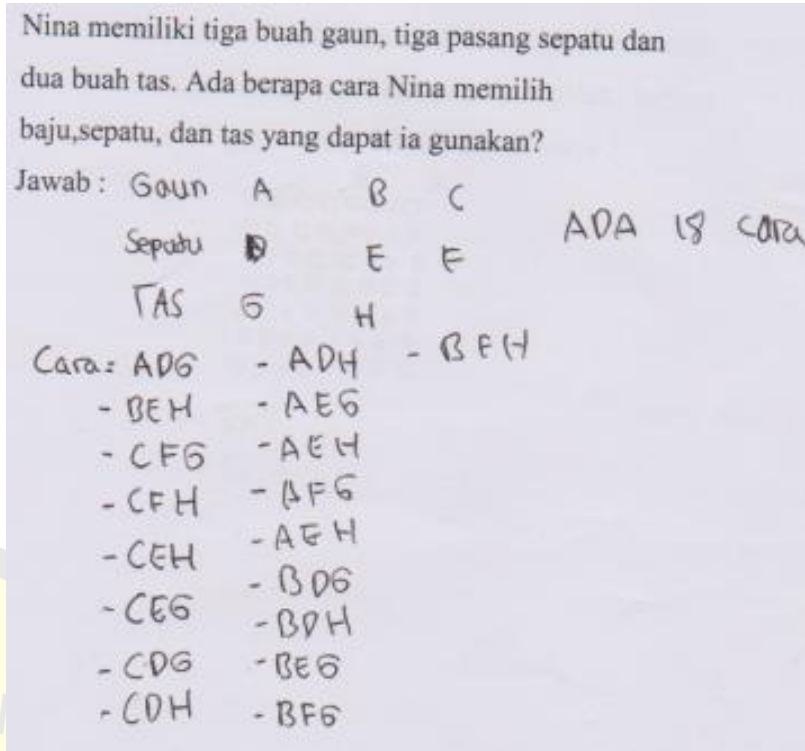

\section{Gambar 6. Hasil Pekerjaan Subjek X}

Sedangkan subjek berkemampuan matematika tinggi perempuan ditemukan hasil pada fase reacting dapat memahami masalah yang dihadapi, menyebutkan apa saja yang diketahui dan ditanyakan pada soal serta dapat menemukan hubungan antara yang diketahui dan yang ditanyakan pada soal. Selanjutnya pada fase elaborating mampu menjelaskan jawaban yang telah didapat dari permasalahan yang telah diselesaikan serta mampu menemukan persamaan dan perbedaan dari permasalahan yang pernah dihadapi sebelumnya dengan permasalahan yang sedang dihadapi. Selanjutnya pada fase contemplating subjek dapat menyelesaikan dan membuat kesimpulan dari soal yang telah diselesaikan. Maka dapat disimpulkan subjek berkemampuan matematika tinggi perempuan memiliki kemampuan berpikir reflektif pada soal cerita tipe combinatorial multiplication. 


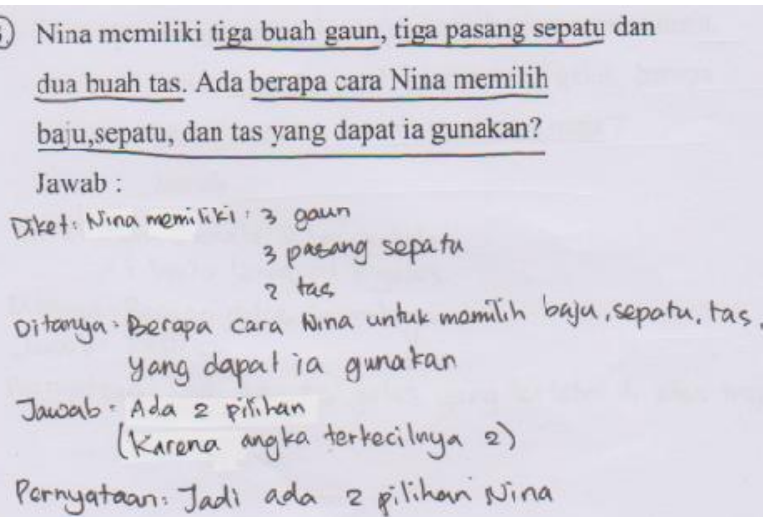

Gambar 7. Hasil Pekerjaan Subjek N

Subjek Berkemampuan Matematika Sedang

Subjek laki-laki S ditemukan hasil pada fase reacting subjek dapat memahami masalah yang dihadapi, mengucapkan apa yang diketahui dan ditanyakan pada soal serta dapat menemukan hubungan antara yang diketahui dan yang ditanyakan pada soal. Selanjutnya pada fase elaborating subjek mampu menjelaskan jawaban yang telah ia peroleh dari permasalahan yang telah ia selesaikan. Pada fase contemplating subjek dapat membuat kesimpulan. Maka dapat disimpulkan bahwa subjek $\mathrm{S}$ memiliki kemampuan berpikir reflektif pada soal cerita tipe combinatorial multiplication.

Sedangkan subjek perempuan A ditemukan hasil pada fase reacting ia dapat memahami masalah yang dihadapi, mengucapkan apa yang diketahui dan yang ditanyakan, serta dapat menemukan hubungan angtara yang diketahui dan yang ditanyakan pada soal. Selanjutnya pada fase elaborating subjek mampu menjelaskan jawaban yang telah didapatkan dari permasalahan yang telah diselesaikan. Maka dapat disimpulkan bahwa subjek A memiliki kemampuan cukup reflektif pada soal cerita tipe combinatorial multiplication.

\section{Subjek Berkemampuan Matematika Rendah}

Subjek aki-laki $\mathrm{G}$ ditemukan hasil pada fase reacting dapat memahami soal yang dimaksud dan pada fase elaborating dapat menyelesaikan soal tersebut dengan cara langsung serta dapat menjelaskan jawaban yang telah diperoleh. Maka dapat disimpulkan subjek $G$ memiliki kemampuan cukup reflektif pada soal cerita tipe combinatorial multiplication.

Subjek perempuan $\mathrm{T}$ ditemukan hasil pada fase reacting dapat memahami soal yang dimaksud dengan menuliskan yang diketahui pada soal serta mengucapkannya pada saat wawancara. Pada fase elaborating ia dapat menyelesaikan soal tersebut serta menjelaskan jawaban yang telah ia peroleh. Selanjutnya pada fase contemplating ia dapat membuat kesimpulan, maka berdasarkan uraian singkat diatas dapat disimpulkan bahwa subjek $\mathrm{T}$ memiliki kemampuan berpikir reflektif pada soal cerita tipe combinatorial multiplication.

\section{Pembahasan}

Berdasarkan hasil penelitian diatas didapatkan kemampuan berpikir reflektif siswa pada masing-masing tipe perkalian. Adapun rangkuman kemampuan berpikir reflektif siswa dapat dilihat pada tabel 3 .

Tabel 3. Rangkuman Kemampuan Berpikir Reflektif Siswa

\begin{tabular}{|c|c|c|c|c|c|}
\hline \multirow[t]{2}{*}{ Subjek } & \multicolumn{3}{|c|}{ Kemampuan Berpikir Reflektif } & \multirow{2}{*}{$\begin{array}{l}\text { Kategor } \\
\text { i } \\
\text { Kemam } \\
\text { puan } \\
\text { Berpikir } \\
\text { Reflektif }\end{array}$} & \multirow{2}{*}{$\begin{array}{l}\text { Kemam } \\
\text { puan } \\
\text { Matema } \\
\text { tika }\end{array}$} \\
\hline & $\begin{array}{l}\text { Scalar } \\
\text { Multiplic } \\
\text { ation }\end{array}$ & $\begin{array}{l}\text { Array } \\
\text { Multiplic } \\
\text { ation }\end{array}$ & $\begin{array}{l}\text { Combina } \\
\text { torial } \\
\text { Multiplic } \\
\text { ation }\end{array}$ & & \\
\hline $\begin{array}{l}\text { Perem } \\
\text { puan }\end{array}$ & Reflektif & Reflektif & Reflektif & Tinggi & Tinggi \\
\hline $\begin{array}{l}\text { Laki- } \\
\text { laki }\end{array}$ & Reflektif & Reflektif & Reflektif & Tinggi & Tinggi \\
\hline $\begin{array}{l}\text { Perem } \\
\text { puan }\end{array}$ & $\begin{array}{l}\text { Cukup } \\
\text { Reflektif }\end{array}$ & $\begin{array}{l}\text { Kurang } \\
\text { reflektif }\end{array}$ & Reflektif & Tinggi & Sedang \\
\hline $\begin{array}{l}\text { Laki- } \\
\text { laki }\end{array}$ & Reflektif & Reflektif & Reflektif & Tinggi & Sedang \\
\hline $\begin{array}{l}\text { Perem } \\
\text { puan }\end{array}$ & Reflektif & Reflektif & Reflektif & Tinggi & Rendah \\
\hline $\begin{array}{l}\text { Laki- } \\
\text { laki }\end{array}$ & $\begin{array}{l}\text { Cukup } \\
\text { Reflektif }\end{array}$ & $\begin{array}{l}\text { Kurang } \\
\text { Reflektif }\end{array}$ & $\begin{array}{l}\text { Kurang } \\
\text { Reflektif }\end{array}$ & Rendah & Rendah \\
\hline
\end{tabular}


Kemampuan berpikir reflektif siswa berkemampuan matematika tinggi laki-laki dan perempuan pada tipe scalar multiplication, array multiplication dan combinatorial multiplication adalah tinggi. Meskipun sama-sama memiliki kemampuan berpikir berflektif tinggi dan dapat melalui ketiga fase dalam berpikir reflektif yaitu reacting, elaborating dan contemplating siswa laki-laki dan perempuan memiliki perbedaan yaitu pada soal tipe scalar multiplication siswa laki-laki cenderung lebih menggunakan ilustrasi contohnya dengan gambar sedangkan subjek perempuan dengan teratur contohnya dengan menuliskan diketahui, ditanya, dijawab, dan menuliskan kesimpulan di akhir penyelesaian. Pada soal tipe combinatorial multiplication subjek lakilaki cenderung menyelesaikan soal dengan cara mengelompokkan dan memisalkan terbukti pada hasil pekerjaan gambar 6 . Sedangkan subjek perempuan menyelesaikan secara teratur dengan menuliskan ditanya, diketahui, dijawab dan kesimpulan serta menyelesaikan secara langsung terbukti pada gambar hasil pekerjaan gambar 7. Selain perbedaan dalam pemilihan cara dalam menyelesaikan soal siswa laki-laki dan perempuan memiliki alasan memilih/cara tersebut. Siswa laki-laki mengungkapkan bahwa dengan cara menggambar dan mengelompokkan dari apa yang diketahui lebih teliti dan cepat, namun berbeda dengan siswa perempuan ia mengungkapkan jika dengan menuliskan diketahui, ditanya dan dijawab adalah cara yang paling tepat dan efisien dibandingkan dengan menggambar karena menggambar akan menghabiskan banyak waktu.

Pada siswa berkemampuan sedang laki-laki dan perempuan juga ditemukan perbedaan. Siswa laki-laki dikatakan reflektif pada ketiga tipe soal yaitu scalar multiplication, array multiplication dan combinatorial multiplication. Sementara subjek perempuan reflektif untuk soal tipe scalar mulyiplication cukup reflektif untuk soal tipe array multiplication dan combinatorial multiplication. Pada soal tipe array multiplication ditemukan perbedaan cara menyelesaikan soal antara siswa laki-laki dan perempuan. Siswa laki-laki menyelesaikan soal cenderung secara langsung dan siswa perempuan menyelesaikan dengan menuliskan diketahui kemudian dijawab. Alasan siswa laki-laki memilih cara langsung karena menurutnya cara tersebut adalah satu-satunya cara yang dirasa mudah dan cepat. Ia juga mengungkapkan menuliskan diketahui, ditanya dan dijawab hanya untuk soal yang ia rasa cukup rumit. Sedangkan siswa perempuan hanya menuliskan diketahui dan dijawab karena menurutnya yang perlu ditulis hanya itu untuk membantu menyelesaikan soal tanpa harus mencari pada soal.

$$
\text { Pada siswa berkemampuan }
$$

matematika rendah laki-laki dan perempuan juga ditemukan perbedaan. Siswa laki-laki dikatakan kurang reflektif pada ketiga tipe soal yaitu scalar multiplication, array multiplication dan combinatorial multiplication. Sementara subjek perempuan reflektif untuk semua tipe soal. Pada soal tipe scalar multiplication ditemukan perbedaan cara menyelesaikan soal antara subjek lakilaki dan perempuan. Siswa laki-laki menyelesaikan soal cenderung secara langsung ketika diminta untuk mengerjakan soal dengan cara yang lain siswa tersebut bisa dan menggunakan gambar sedangkangkan untuk siswa perempuan menyelesaikan dengan menuliskan diketahui kemudian dijawab lalu menuliskan kesimpulan. Siswa 
perempuan ketika diminta untuk mengerjakan kembali dengan cara yang lain ia tidak bisa karena ia merasa cara yang sudah ia lakukan adalah cara satu-satunya.

Temuan pada penelitian ini adalah kemampuan berpikir reflektif siswa pada soal tipe-tipe perkalian tidak berada pada tingkatan kemampuan berpikir reflektif yang sama. Keenam subjek dalam menyelesaikan masalah berdasarkan soal tipe-tipe perkalian menggunakan caranya sendiri melalui gambar dan menuliskan secara rinci apa saja yang diketahui. Selain itu juga ditemukan tidak ada subjek yang memiliki kemampuan berpikir reflektif sangat tinggi, karena tidak ada subjek memiliki kemampuan berpikir reflektif atau melalui semua fase berpikir reflektif yaitu reacting, elaborating dan contemplanting pada semua tipe soal. Hal ini menunjukkan hasil yang berbeda dengan penelitian sebelumnya mengenai proses berpikir reflektif siswa dalam memecahkan masalah matematika non rutin ditinjau dari kemampuan awal matematika tinggi, sedang dan rendah (Lutfiananda, 2016, hal.4). Didapatkan hasil siswa dengan kemampuan awal matematika tinggi menunjukkan proses berpikir reflektif dengan melalui semua tahapan pemecahan masalah, siswa berkemampuan matematika sedang menunjukkan proses berpikir reflektif dengan melalui tiga tahapan pemecahan masalah dan siswa berkemampuan awal matematika rendah hanya dapat menunjukkan karakteristik proses berpikir reflektif. Profil berpikir reflektif siswa SMP dalam pemecahan masalah pecahan ditinjau dari perbedaan gender menunjukkan siswa lakilaki dan perempuan dapat melalui semua tahapan dalam berpikir reflektif dan pemecahan masalah (Rasyid, 2017, hal.12). Namun pada salah satu fase ditemukan perbedaan yaitu pada siswa perempuan ia tidak mempertimbangkan pengalamannya untuk memecahkan suatu permasalahan.

\section{Simpulan Dan Saran}

\section{Simpulan}

Berdasarkan hasil dan pembahasan dapat disimpulkan bahwa kemampuan berpikir reflektif siswa berkemampuan matematika tinggi, sedang, dan rendah tidak berada pada fase atau tingkatan berpikir reflektif yang sama. Subjek berkemampuan matematika tinggi dan sedang laki-laki dan perempuan memiliki kemampuan berpikir reflektif tinggi pada ketiga tipe perkalian karena dapat melalui tiga fase dalam berpikir reflektif yaitu fase reacting, elaborating, dan contemplating. Subjek berkemampuan matematika rendah perempuan memiliki kemampuan berpikir reflektif tinggi karena dapat melalui tiga fase dalam berpikir reflektif yaitu fase reacting, elaborating, dan contemplating.

Hasil penelitian ini diharapkan dapat memberikan gambaran kepada guru dan peneiti yang lain mengenai berpikir reflektif siswa berkemampuan tinggi, sedang, rendah pada tipe-tipe perkalian dan dapat mengetahui tingkatan berpikir reflektif siswa.

\section{SARAN}

Berdasarkan hasil dan pembahasan pada penelitian ini yang dapat disimpulkan bahwa siswa perempuan cenderung berpikir reflektif daripada siswa laki-laki. Selain itu siswa laki-laki yang cenderung menggunakan ilustrasi dan siswa perempuan cenderung dengan cara yang teratur. Guru diharapkan lebih sering melatih siswa laki-laki dalam berpikir reflektif dan lebih menekankan lagi 
proses dari pada hasil karena siswa laki-laki menyelesaikan permasalahan cenderung dengan ilustrasi dan tidak menggunakan konsep seharusnya. Mengingat pentingnya berpikir reflektif dalam menyelesaikan suatu permasalahan sehingga nantinya baik siswa laki-laki maupun siswa perempuan dapat menyelesaikan permasalahan yang lebih kompleks.

\section{DAFTAR PUSTAKA}

Ahmad. (2011). Artikel Berpikir Reflektif. Diakses pada tanggal 19 Februari 2017 dari http://dahliahmad.blogspot.co.id/2011/05/berfikirreflektif.html

Asmaningtyas. (2012). Kemampuan Matematika Laki-laki dan Perempuan Jurnal UIN Malang. Diakses pada tanggal 29 Januari dari http://ejournal.uinmalang.ac.id/index.ph p.tarbiyah/article/download/1840/pdf

Azhari. (2017). Kemampuan Berpikir Reflektif dalam Memecahkan Masalah pada Siswa Kelas VII-C MTsN Ngantru Tulungagung. Diakses pada tanggal 8 November 2017 dari http://repo.iaintulungagung.ac.id/6259/

Cendekiawaty. (2016). Deskripsi Kemampuan Berpikir Reflektif Matematis Siswa SMP Istiqomah Sambas Purbalingga ditinjau dari Gender. Diakses pada tanggal 8 November $2017 \quad$ dari http://repository.ump.ac.id/1403/3/BAB \%20II_TIARA\%20CENDEKIAWATY _MATEMATIKA\%2716.pdf

Fascual, Ferrari. Developmental Relations among Mind, Brain and Education 265270.

Ismail. (2013). Teori Berpikir Reflektif John Dewey. Diakses pada tanggal 19 Februari 2017 dari http:/gumilarismail.blogspot.co.id/2013 /11/teori-berpikir-reflektif-johndewey.html
Mahmudi, Ali (2008). Pembelajaran Problem Posing untuk Meningkatkan Kemampuan Pemecahan Masalah Matematika.

Nafi'an, M.I (2011). Kemampuan siswa dalam menyelesaikan soal cerita ditinjau dari gender di sekolah dasar. Seminar Nasional Matematika dan Pendidikan Matematika FMIPA UNY, $P(53)$, 573-574

Rita. (2010). Penerapan Model Pembelajaran Problem Solving. Diakses tanggal 15 Maret 2017 dari http://s3.amazonams.com/academia.edu. documents.html.

Santrock, J.W (2011). Remaja Edisi 1, 227235

Suharna, Heri (2012). Berpikir reflektif (reflektive thinking) siswa SD berkemampuan matematika tinggi dalam pemahaman masalah pecahan. Seminar Nasional Matematika dan Pendidikan Matematika FMIPA UNY, P(41), 376-386.

Surbeck, E., Han, E. P., \& Moyer, J. (1991). "Assessing reflective responses in journals". Educational Leadership 48, pp. 25-27.

Wahyuni. (2012). Artikel Pemecahan Masalah. Diakses tanggal 15 Maret 2017 dari http://mahasiswa.mipastkippllg.com/rep ository/artikel

Widjajanti. (2009). Kemampuan Pemecahan Masalah Matematis Mahasiswa Calon Guru Matematika:APA dan BAGAIMANA MENGEMBANGKANNYA. Diakses pada tanggal 20 Maret 2017 dari hhtp://core.ac.uk/download/pdf/1106462 3.pdf.html 